\title{
Productivity and Grazing Behavior of Ewes with Single or Twin Lambs Raised in Mixed Italian Ryegrass/White Clover Pasture in Southern Brazil
}

\author{
Felipe Jochims ${ }^{1 *}$, Cleber Cassol Pires ${ }^{1}$, Malcolm J. Gibb², Eduardo Bohrer de Azevedo3, \\ Diego Bitencourt de David ${ }^{3}$, Émerson Mendes Soares ${ }^{1}$ \\ ${ }^{1}$ Federal University of Santa Maria, Animal Science Department, Santa Maria, Brazil \\ ${ }^{2}$ Formerly at the Institute of Grassland and Environmental Research, North Wyke, UK \\ ${ }^{3}$ Federal University of Rio Grande do Sul, Animal Science Department, Porto Alegre, Brazil \\ Email: ${ }^{*}$ felipejochims@yahoo.com.br
}

Received 14 January 2014; revised 16 February 2014; accepted 6 March 2014

Copyright @ 2014 by authors and Scientific Research Publishing Inc.

This work is licensed under the Creative Commons Attribution International License (CC BY). http://creativecommons.org/licenses/by/4.0/

\section{Open Access}

\section{Abstract}

The aim of this study was to compare the area production and grazing behavior of single- and twin-rearing ewes kept on a mixed Italian ryegrass/white clover pasture. The herbage allowance was maintained at $12 \mathrm{~kg} D M / 100 \mathrm{~kg}$ live weight during the experiment, by continuous variable stocking management for 112 days (4 periods of 28 days). We measure the live weight gains, the area production and the body condition score of ewes and lambs. Animal behavior was observed on four occasions during which we evaluated whether the lambs were grazing near to or far from their mother. Live-weight output from the ewes and lambs, and net output (ewes and lambs) were calculated. Results showed that being irrespective of birth type, ewes had similar mean daily weight gains, although ewes with twin lambs presented a mean lower body condition score. Ewes live weight output/ha did not differ significantly among birth types, but twin lambs produced 98.2 kg (45\%) more live weight gain/ha. Total net live-weight output (ewes + lambs) was $121.5 \mathrm{~kg}$ greater for twins than for singles. Ewes with twin lambs spent more time grazing and ruminating. Lambs increased the time they spent grazing in each successive period. Single lambs spent significantly longer time grazing within $\mathbf{1 2} \mathrm{m}$ of their dams (near grazing). Analysis of far grazing times by the broken line method showed that growing lambs rapidly increase the time spent far grazing up to a live weight of $20.3 \mathrm{~kg}$ in both birth types, which occurs at 95.3 and 115.9 days of age for single and twins, respectively. The results indicate that twin lambs are more productive than singles, when evaluated per area unit of pasture.

Corresponding author.

How to cite this paper: Jochims, F., Pires, C.C., Gibb, M.J., De Azevedo, E.B., De David, D.B. and Soares, É.M. (2014) Productivity and Grazing Behavior of Ewes with Single or Twin Lambs Raised in Mixed Italian Ryegrass/White Clover Pasture in Southern Brazil. American Journal of Plant Sciences, 5, 963-974. http://dx.doi.org/10.4236/ajps.2014.57109 
Keywords

Area Weight Gain; Birth Type; Herbage Allowance; Lambs Daily Weight Gain; Sheep

\section{Introduction}

The sheep industry plays an important role in animal production systems in Southern Brazil. There are about four million sheep in this region, representing $30 \%$ of the Brazilian flock [1]. The region is situated in the Campos Grasslands [2], Southern Brazil, and the natural pastures found there provide the most important feed resource for ruminants in extensive farming systems. An important characteristic of this region is that the natural grasslands are almost exclusively composed by C4 metabolic cycle plants [3] and in the winter months presents lower growth rates and a decline in herbage quality [4].

To overcome this deficiency, in the winter, farmers use annual pastures, such as Italian ryegrass (Lolium multiflorum Lam.) and/or mixed pastures, such as Italian ryegrass and white clover (Trifolium repens L.). These winter pastures have high nutritional quality, at a time when the nutritional requirements of sheep are increasing at the end of pregnancy and in early lactation, especially when the ewe has twin lambs.

The scientific literature reports divergent results when comparing with lambing types and often concludes that single lambs are better because of their higher individual performance and reduced time to reach slaughter weight [5]-[7] when, in fact, these results are due to differences in birth weight and the availability of milk for the lambs [8]. Such results ultimately can affect the selection against animals born as twins in local production systems if these differences between birth type were not considered.

International literature has revealed that ewes with more than one lamb show an increase in dry matter intake and an increase in milk production at the beginning of lactation [8] [9]. Recently, similar studies have been conducted locally, but have focused on individual daily live-weight performance of lambs, dry matter intake by lambs and ewes, and their subsequent milk production. However, the system productivity is not measured. In this way, the objective of this study was to compare productivity due to birth type (single vs twin), taking into account the total weight production per area, as well as the feeding behavior of ewes and lambs, when all animals are kept on good quality pasture and with the same feeding conditions.

\section{Material and Methods}

\subsection{Locality, Pasture, Treatments and Grazing Management}

The study was conducted at Santa Maria Federal University (UFSM), Animal Science Department area. The area is in the region called Central Depression of Rio Grande do Sul state, south Brazil, at an altitude of $95 \mathrm{~m}$, located at $29^{\circ} 43^{\prime}$ latitudes, $53^{\circ} 42^{\prime} \mathrm{W}$. The climate is humid subtropical (Cfa) according to the Köppen classification [10].

A 3-ha area of mixed Italian ryegrass (Lolium multiflorum Lam.) and white clover (Trifolium repens L. cv. Zapican) pasture was divided into four experimental units of about 0.75 ha each, plus an area for the put-and-take animals, which were ewes with male lambs, used to adjust grazing pressure when necessary. The pasture had been sown on May 27th (35 kg/ha of Italian ryegrass and $5 \mathrm{~kg} / \mathrm{ha}$ of white clover seeds), when 250 $\mathrm{kg} / \mathrm{ha}$ of 5-20-20 (N-P-K) formula fertilizer was applied. A top dressing of $45 \mathrm{~kg} \mathrm{~N}$, as urea, was applied on October 10th. The experiment was conducted over four consecutive 28-day periods, from July 16th to November 5th, comprising 112 days of continuous grazing, during which two birth types were studied: single-ewes with one ewe lamb, and twin-ewes with two ewe lambs.

The four paddocks were used to provide two spatial replicates for two groups each of the single- and twin-rearing ewes. Each single-rearing group contained four ewes and their lambs and each twin-rearing group contained four ewes and their lambs as test-animals. The Texel $\times$ Ile de France ewes in the experiment had been mated to Texel rams and were 5 years old with a mean live weight of $48.4 \pm 3.56 \mathrm{~kg}$ and a body condition score (BCS) of $2.9 \pm 0.3$ at the beginning of the experiment. The single and twin lambs were a mean of $37.8 \pm 5.9$ and $38.4 \pm 4.9$ days old, with mean live weights (LW) of $10.5 \pm 3.42$ and $7.8 \pm 3.76 \mathrm{~kg}$, respectively, when the experiment began. 
Swards were maintained by continuous variable stocking management, using the additional put-and-take ewes and their lambs to provide an herbage allowance of $12 \mathrm{~kg} \mathrm{DM} / 100 \mathrm{~kg}$ ewe and lamb live weight during the entire experimental period. Adjustments to the grazing pressure were made every 14 days, based on current measurements of herbage mass, herbage growth rate and the LW of the ewes and lambs. All animals had unrestricted access to clean water, mineral supplements and natural shade throughout the experiment.

\subsection{Pasture Measurements}

Herbage mass (HM) was estimated every 14 days using a direct visual estimation double-sampling technique [11], with seven cuts at the ground level, within $50 \times 50 \mathrm{~cm}$ quadrats and 30 visual estimations per paddock. The herbage from the cuts was homogenized, divided into two sub-samples and weighed, one to determine dry matter content and another for botanical and morphological separation. These samples were weighed and dried in a forced-air oven at $65^{\circ} \mathrm{C}$ for at least 72 hours. By manual separation was determinate the species mass (Italian ryegrass or white clover) and the morphological components mass of the pasture. The mass of leaf lamina; pseudostem, stem and flowering stems; dead herbage and the lamina:pseodostem ratio were calculated as the product of total herbage mass and the component in question percentage.

The net herbage accumulation was assessed according to [12]. First, it was selected two similar locations, using $50 \times 50 \mathrm{~cm}$ quadrats. In one, were allocated one cage and another, the herbage was cut in the ground level, dried and weighted. After 14 days, the quadrat into the cage were cut, dried and weighted. The difference of weight was transformed in DM/ha and divided by the interval days. It was used three cages for paddock to avoid the graze activity in that area, totalizing six evaluations of herbage accumulation per treatment. In both evaluations the samples were weighted before the cuts as green herbage and dried in an oven at $65^{\circ} \mathrm{C}$ for 72 hours and weighted to obtain the dry matter content (\% DM).

Samples of the representative herbage eaten by the sheep were collected by hand-plucking, following the procedure described by [13]. Samples were weighed, dried in an oven at $55^{\circ} \mathrm{C}$ for 72 hours, reweighed and ground before laboratory analysis. Herbage nitrogen content was determined according to the kjeldahl method as described in AOAC methods no. 2.036 [14] and no. 2.049 [15]. The nitrogen content was expressed as crude protein $(\mathrm{CP}, \mathrm{N} \times 6.25)$. The in vitro organic matter digestibility was determined according to [16], and neutral detergent fiber, exclusive of ash and without amylase (NDF), according to [17].

The mean herbage allowance (1) (HA, kg of DM/100 kg LW) was calculated as follows:

$$
\mathrm{HA}=(((\mathrm{HM} \div \mathrm{PD})+\mathrm{DNHA}) \div \mathrm{TSR}) \times 100
$$

Where, HM is the total herbage mass from each period (DM kg/ha); PD is the number of days in the period; DNHA is the mean daily net herbage accumulation (DM kg/ha); TSR is the mean total stocking rate within each paddock (kg/ha) in each period. The DNHA was obtained according item 2.2.

The mean ryegrass leaf/clover allowance (2) (RCA, kg DM/100kg LW) was calculated as:

$$
\text { RCA }=((\text { RLm }+ \text { Cm })+((\text { HMfin } \times(\text { PRLfin }+ \text { PCfin }))-(\text { HMinit } \times(\text { PRLinit }+ \text { PCinit }))) \div \text { TSR }) \times 100 .
$$

Where, RLm and Cm are the ryegrass leaf and clover mass, respectively; HMinit and HMfin are the herbage mass (DM kg/ha), PRLinit and PRLfin are the proportions of ryegrass leaf, and PCinit and PCfin are the proportions of clover, each determined at the beginning and end of the 14-day period of DNHA measurement, respectively; TSR is the mean total stocking rate from each paddock (kg/ha).

\subsection{Animal Measurements}

Ewes and lambs were weighed at the beginning of the experiment and every 28 days thereafter, following a 12-hour fasting period, using a 50 g precision balance. On these occasions, ewe body condition score (BCS) was also assessed by palpation of the transverse processes of the lumbar vertebrae, and scored using a 5-point scale where: 1 = very thin and 5 = very fat; with intermediate increments of 0.5 points [18]. The mean daily live-weight gain (3) was calculated, each 28 days, as follows:

$$
\text { DWGP }=(B W b-B W a) \div P D \text {. }
$$

where, DWGp is the mean daily LW gains in each period; BWb is the weight at the end of each period (28 days); 
BWa is the body weight at the beginning of each period; PD days between weightings. This operation was realized four times, with 28 days of interval and all animals were weighted individually and the mean values from each paddock (ewes or lambs) were used as result.

The total stocking rate (4), in LW kg/ha, in each period, was calculated as follows:

$$
\mathrm{TSR}=((\mathrm{LWe}+\mathrm{LWl}) \times \mathrm{PD})+(\mathrm{LWr} \times \mathrm{D}) \div \mathrm{PD}
$$

where, LWe and LWl is the live weight of ewes and lambs, respectively; PD is the number of days in each period; BWr is the combined body weight of the "put-and-take" animals; D is the number of days the put-and-take animals were kept into the paddocks.

Three expressions of weight output per ha were calculated: ewes, lambs and net weight output (ewes + lambs), within each period. The calculations of ewes and lambs LW gains per area (5) were performed as follows:

$$
\mathrm{LWO}=(\mathrm{SRc} \div \mathrm{MLWc}) \times(\mathrm{DLWGc} \times \mathrm{PD})
$$

where, LWO is the live weight output per area (kg/ha); SRc is the category stocking rate $(\mathrm{kg} / \mathrm{ha})$; MLWc is the category mean live weight; DLWGc is the category mean daily weight gain; PD is the period length, in days.

The separate calculation of live-weight output by ewes (LW Output ewes) and lambs (LW Output lambs), per ha, within each 28-day period was performed in order to identify when animals might have undergone poor or negative live-weight gains. Live weight output over the entire experimental period was calculated as the arithmetic sum of their performance in each period. The expression "total net live weight output" (TLW Output) applies to the sum of ewe and lamb live weight gains per ha.

\subsection{Animal Behavior Measurements}

Four 24-h grazing behavior recordings were conducted every 28 days, beginning on 8th August, 24th day of the trial. At night, low light intensity lanterns were used, and a distance threshold of, at least, $20 \mathrm{~m}$ from the animals was respected to avoid disturbance to the natural behavior. Visual observations were made every ten minutes [19], to register grazing [20], ruminating and other activities [21] by both ewes and lambs. The recorded activities were assumed to be representative of that occurring throughout a 10-minute period and were expressed in min/day. In the observations of lamb grazing activity, the proximity of the lambs to their dam was recorded as "near grazing" or "far grazing". Far grazing was defined as when lambs were grazing at least 12 meters away from their dam and were not looking for each other (e.g. bleating loudly; [22]). To this, other two evaluators were responsible for the social behavior of the lambs. When the lambs were grazing at a distance of less than 12 meters or searched for their dam was recorded as "near grazing". To facilitate identification, the lambs were identified with the same number as their dam, with permanent sheep marker. Single and twin lambs had mean age of 51 and 52 days old, respectively, at the first behavior observation.

The lambs "near" and "far" grazing is an attempt to identify the lambs maturity increase as well the increasing experience and confidence of the lambs and an acquired security over time with the grazing learning [23]. This is an attempt to identify the "best" welfare moment to wean the lambs.

\subsection{Statistical Analysis}

The experiment was conducted as a completely randomized design with repeated measures in time, with two treatments and two replicates (paddock), resulting in four experimental units. For all variables studied, the experimental unit was the paddock group. A variance analysis was conducted with the model including the effects of treatment, period and treatment $\times$ period interaction with a significance level of $5 \%$. When significant differences were detected between the means, they were compared by Tukey test, with a $5 \%$ significance level. Tests were performed using the PROC MIXED of SAS 9.2 software, using the CS covariance structure (Compound Symmetry), chosen by the lower AIC (Akaikes information criteria) among other structures. All data present normal statistic distribution.

Separate regression analyses were conducted, with individual data from the lambs, to examine the effect of LW on far grazing times recorded for each single or twin lamb in each of the four periods, as a measure of the effect of LW on the confidence and experience of the lambs to graze away from its dam. The method of segmented regression was used (broken line), in each treatment, using PROC NLIN procedure of SAS 9.2. Using the value of the point where the far grazing line changed direction and showed no further response to increase in 
LW, a variance analysis was performed to verify the effect of birth type. With simple regression analysis, plotting the age in days in relation to live weight, the age of this stabilization was calculated.

\section{Results}

\subsection{Sward Results}

Herbage mass, herbage net accumulation rate and other structural variables of the experimental swards did not differ significantly $(P>0.05)$ between the birth types, periods and did not demonstrate treatment $\times$ period interactions (Table 1). The ryegrass mass increased from periods 1 to 4 and the clover mass decreased during the trial. The mass of pseudostem and dead material in the sward also increased significantly over time. However, there was a decrease in the leaf:pseodostem ratio from periods 1 to 4 . Despite the increase in total ryegrass mass over the four periods, the quantity of ryegrass leaf mass did not differ significantly between the evaluation periods.

The mean total daily herbage allowance did not differ between the birth types or among periods. However, the mean daily herbage allowance calculated as ryegrass leaf and clover mass, showed a significant decline from periods 1 to 4 . About the apparently consumed herbage (hand plucking samples), the in vitro OM digestibility, neutral detergent fiber and crude protein levels did not differ significantly between sward accommodating the two birth type groups. Whilst in-vitro OM digestibility and crude protein content decreased significantly from periods 1 to 4 , the NDF content increased according to the herbage age increases.

\subsection{Animal Performance}

There was no significant difference to birth type or periods effects on total stocking rate (SR, Table 2). Despite the $8 \%$ greater stocking rate of ewes (SR ewes), overall, attributed to single-rearing ewes compared with twinrearing ewes, there was no significant birth type or periods effects on SR ewes. The lambs stocking rate (SR lamb) differed significantly between birth types and periods, showing a significant linear increase over periods 1 to 4 . The SR lambs in the twin paddocks presented a $28 \%$ higher SR lamb. The SR lambs showed significant

Table 1. Herbage mass (HM), herbage net accumulation rate (HAR), ryegrass mass, clover mass, pseodostem mass, dead herbage mass, leaf:pseudostem ratio (L:PS ratio), ryegrass lamina mass, total herbage allowance (THA), ryegrass leaf/clover allowance (RCHA; kg DM/100kg LW) and chemical composition of hand plucking: In-vitro OM digestibility (OMD); neutral detergent fiber content (NDF); crude protein content (CP; g/100g DM )) in a mixed sward of Italian ryegrass and white clover managed with different birth types ( $T$, singles vs. twins) and different periods (Per).

\begin{tabular}{|c|c|c|c|c|c|c|c|c|c|}
\hline & \multicolumn{2}{|c|}{ Birth type (T) } & \multicolumn{4}{|c|}{ Period (Per) } & \multicolumn{2}{|c|}{ Significance of effect $(\mathrm{P}=$ ) } & \multirow{2}{*}{$\mathrm{RSD}^{1}$} \\
\hline & Single & Twin & 1 & 2 & 3 & 4 & $\mathrm{~T}$ & Per & \\
\hline \multicolumn{10}{|l|}{ Pasture variables } \\
\hline HM (DM kg/ha) & 1538 & 1627 & 1547 & 1490 & 1571 & 1721 & 0.423 & 0.487 & 195.3 \\
\hline HAR (DM kg/ha/d) & 67 & 61 & 61 & 60 & 77 & 59 & 0.260 & 0.100 & 12.1 \\
\hline Ryegrass (DM kg/ha) & 1371 & 1455 & $1192^{\mathrm{b}}$ & $1303^{\mathrm{ab}}$ & $1471^{\mathrm{ab}}$ & $1685^{\mathrm{a}}$ & 0.412 & 0.033 & 256.9 \\
\hline Clover (DM kg/ha) & 167 & 171 & $354^{\mathrm{a}}$ & $186^{\mathrm{b}}$ & $100^{c}$ & $35^{\mathrm{c}}$ & 0.831 & $<0.001$ & 130.6 \\
\hline Pseodostem (DM kg/ha) & 341 & 371 & $250^{\mathrm{b}}$ & $297^{\mathrm{b}}$ & $377^{\mathrm{ab}}$ & $499^{\mathrm{a}}$ & 0.325 & 0.001 & 112.1 \\
\hline Dead herbage (DM kg/ha) & 99 & 107 & $41^{\mathrm{c}}$ & $71^{\text {bc }}$ & $111^{\mathrm{b}}$ & $189^{\mathrm{a}}$ & 0.471 & $<0.001$ & 61.4 \\
\hline L:PS ratio & 2.86 & 2.82 & $3.62^{\mathrm{a}}$ & $3.13^{\mathrm{ab}}$ & $2.60^{\mathrm{b}}$ & $2.01^{\mathrm{c}}$ & 0.738 & $<0.001$ & 0.6 \\
\hline Ryegrass leaf mass & 930 & 976 & 901 & 934 & 982 & 977 & 0.484 & 0.701 & 114.6 \\
\hline Total HA & 13 & 12.3 & 13.1 & 12.1 & 13.4 & 12.1 & 0.148 & 0.100 & 0.9 \\
\hline RC-HA & 9.3 & 8.8 & $10.7^{\mathrm{a}}$ & $9.1^{\mathrm{b}}$ & $9.3^{\mathrm{ab}}$ & $7.2^{\mathrm{c}}$ & 0.110 & $<0.001$ & 1.4 \\
\hline \multicolumn{10}{|l|}{ Hand Plucking samples } \\
\hline $\mathrm{OMD}(\mathrm{g} / 100 \mathrm{~g})$ & 64.4 & 65.1 & $65.4^{\mathrm{a}}$ & $66.1^{\mathrm{a}}$ & $64.5^{\mathrm{ab}}$ & $63^{b}$ & 0.233 & 0.016 & 1.5 \\
\hline NDF $(g / 100 g)$ & 47.4 & 47.2 & $45^{\mathrm{c}}$ & $46.2^{\mathrm{c}}$ & $47.8^{\mathrm{b}}$ & $50.3^{\mathrm{a}}$ & 0.697 & $<0.001$ & 2.2 \\
\hline CP (g/100g) & 21.9 & 21.9 & $24.5^{\mathrm{a}}$ & $23^{\mathrm{b}}$ & $21.2^{c}$ & $18.8^{\mathrm{d}}$ & 0.849 & $<0.001$ & 2.3 \\
\hline
\end{tabular}

Values within lines followed by different lowercase letters differ by Tukey test $(\mathrm{P}<0.05) .{ }^{1}$ Residual standard deviation 
Table 2. Mean stocking rate (SR), mean ewes and lambs SR, mean ewes body condition score (BCS), mean daily weight gains (DWG, g/day) of ewes and lambs, mean live weight outputs from ewes and lambs (LW Output; $\mathrm{kg} / \mathrm{ha}$ ) and total net LW output (kg/ha) of different birth types in different periods managed in a mixed Italian ryegrass/white clover pasture.

\begin{tabular}{ccccccccccc}
\hline & \multicolumn{3}{c}{ Birth type (BT) } & \multicolumn{4}{c}{ Periods (Per) } & \multicolumn{3}{c}{ Effect (P =) } \\
\hline & Single & Twins & 1 & 2 & 3 & 4 & BT & Per & RSD \\
\hline SR (LW kg/ha) & 939 & 964 & 882 & 934 & 992 & 998 & $\mathrm{~ns}$ & $\mathrm{~ns}$ & 96.8 \\
SR ewes (kg/ha) & 674 & 624 & 664 & 645 & 653 & 634 & $\mathrm{~ns}$ & $\mathrm{~ns}$ & 54.4 \\
SR lambs (kg/ha) & $265^{\mathrm{B}}$ & $340^{\mathrm{A}}$ & $218^{\mathrm{b}}$ & $288^{\mathrm{ab}}$ & $339^{\mathrm{a}}$ & $364^{\mathrm{a}}$ & $* *$ & $* * *$ & 68.4 \\
BCS ewes & $2.6^{\mathrm{A}}$ & $2.3^{\mathrm{B}}$ & $2.2^{\mathrm{b}}$ & $2.5^{\mathrm{a}}$ & $2.5^{\mathrm{a}}$ & $2.5^{\mathrm{a}}$ & $* *$ & $* *$ & 0.18 \\
DWG ewes (g/day) & 35 & 56 & $43^{\mathrm{b}}$ & $18^{\mathrm{bc}}$ & $6^{\mathrm{c}}$ & $116^{\mathrm{a}}$ & $\mathrm{ns}$ & $*$ & 6.06 \\
DWG lambs (g/day) & 140 & 136 & $195^{\mathrm{a}}$ & $91^{\mathrm{c}}$ & $126^{\mathrm{b}}$ & $140^{\mathrm{b}}$ & $\mathrm{ns}$ & $* *$ & 4.04 \\
LW Output ewes (kg/ha) & 13.4 & 19.2 & $15.7 \mathrm{~b}$ & $5.4 \mathrm{c}$ & $2.7 \mathrm{c}$ & $41.2 \mathrm{c}$ & $\mathrm{ns}$ & $*$ & 21.8 \\
LW Outputlambs (kg/ha) & $54.2^{\mathrm{B}}$ & $77.4^{\mathrm{A}}$ & $93.8^{\mathrm{a}}$ & $42.1^{\mathrm{c}}$ & $61.3^{\mathrm{b}}$ & $65.9^{\mathrm{b}}$ & $* *$ & $* * *$ & 21.2 \\
Total LWOutput (kg/ha) & $67.5^{\mathrm{B}}$ & $96.5^{\mathrm{A}}$ & $109.5^{\mathrm{a}}$ & $47.5^{\mathrm{b}}$ & $63.9^{\mathrm{b}}$ & $107^{\mathrm{a}}$ & $* *$ & $* *$ & 32.3 \\
\hline
\end{tabular}

Values within lines followed by different uppercase letters differ by Tukey test $(\mathrm{P}<0.05)$ in birth types; Values within lines followed by different lowercase letters differ by Tukey test $(\mathrm{P}<0.05)$ in periods; RSD = residual standard deviation; ns-non significant, ${ }^{*} 0.05 ;{ }^{* *} 0.01,{ }^{* * *}<0.01$.

treatment $\times$ period interaction, when in the first period the SR lambs was equal, with a mean of $218 \mathrm{~kg} \mathrm{LW} / \mathrm{ha}$. In period 2, 3 and 4 the SR lambs was heavier than the paddocks with single lambs. In period 2, paddocks with single stays with $254 \mathrm{~kg} \mathrm{LW}$ and to twins $322 \mathrm{~kg} / \mathrm{LW}$. In period 3, the SR from singles was $280 \mathrm{~kg} / \mathrm{LW}$ and to twins $399 \mathrm{~kg} / \mathrm{LW}$. In the last period, SR of singles was $315 \mathrm{~kg} / \mathrm{LW}$ and to twins $412 \mathrm{~kg} / \mathrm{LW}$ ha.

The body condition score (BCS) of the ewes increased significantly from the first to second period, but then showed no significant change during the remaining periods. Overall, ewes with single lambs maintained a significantly higher BCS than those with twins, although within individual periods the difference was only significant in period 1 , so only the means were presented. There was no significant birth type $\times$ period interaction effect on BCS.

The mean daily LW gain by ewes (DWG ewes) did not differ significantly between those rearing twin and those rearing single lambs and showed high variability between individual ewes. Differences were found in DWG ewes to the periods, with the higher mean DWG ewes in period 4. The mean daily LW gain of lambs (DWG lambs) did not differ significantly between singles and twins, but did differ significantly between periods, showing a reduction of more than $50 \%$ from period 1 to period 2, following the tendency of the DWG from the ewes, but with a significant recovery in periods 3 and 4 . There were no significant interactive effects of birth type and period.

Mean live weight output from the ewes (LW Output ewes) did not differ significantly between birth types, only for periods, being higher in the last period, following the results from DWG ewes. There was a significant reduction in LW Output in period 2, with some slight recovery in periods 3 and 4. However, mean LW Output lambs differed significantly between birth types and periods. Overall, twin lambs achieved a $43 \%$ greater LW output than single lambs.

The total live weight output (TLW Output, in $\mathrm{kg} / \mathrm{ha}$ ) differed significantly between periods and between birth types with mean output by twin lambs being $43 \%$ greater than that by single lambs. LW Output of ewes or lambs, and TLW Output did not show any significant treatment $\times$ period interactions.

Total ewes, lambs and net (ewes + lambs) live weight gains output (sum of periods productivity, in $\mathrm{kg} / \mathrm{ha}$ ) per area unit (Table 3) shows that the twin lambs produce $42.8 \%$ more weight in the same area unit when compared to single lambs, despite the ewes productivity are equal. The net LW gains per area (sum of ewes and lambs) all show that, when the paddocks were managed with twin birth type, the productivity is $43 \%$ higher that the paddocks managed only with ewes with a single lamb.

\subsection{Animal Behavior}

Ewes with twin lambs spent significantly more time grazing and less time on other activities than the ewes with a single lamb (Table 4). Grazing time increased and the time spend in other activities decreased significantly over time. Ruminating time did not differ between birth type or periods $(\mathrm{P}>0.05)$. All ewes behavior variables showed no treatment $\times$ period interactions. 
Table 3. Total ewes, lambs and net (ewes + lambs) live weight gains output (kg/ha) according to the birth type (single or twin), managed in mixed Italian ryegrass/white clover pastureover 112 days.

\begin{tabular}{cccc}
\hline Birth type & Total ewe weight output (LW kg/ha) & Total lamb weight output (LW kg/ ha) & Total Net weight output (LW kg/ ha) \\
\hline Single & 53.4 & $216.7^{\mathrm{B}}$ & $270^{\mathrm{B}}$ \\
Twin & 76.6 & $309.5^{\mathrm{A}}$ & $386^{\mathrm{A}}$ \\
Significance $(P=)$ & 0.119 & 0.017 & 0.024 \\
RSD $^{1}$ & 15.2 & 54.6 & 68.7 \\
\hline
\end{tabular}

Values within columns followed by different letters differ by Tukey test $(\mathrm{P}<0.05) ;{ }^{1}$ Residual standard deviation.

Table 4. Grazing and ruminating behavior (min/day) by ewes and lambs from single or twin birth types, stocked on a mixed Italian ryegrass/white clover pasture over four 28-day periods.

\begin{tabular}{|c|c|c|c|c|c|c|c|c|c|}
\hline & \multicolumn{2}{|c|}{ Birth Type } & \multicolumn{4}{|c|}{ Period } & \multicolumn{2}{|c|}{ Significance of effect $(\mathrm{P}=)$} & \multirow{2}{*}{ Residual standard deviation } \\
\hline & Single & Twins & 1 & 2 & 3 & 4 & $\mathrm{BT}$ & $\mathrm{P}$ & \\
\hline Ewe grazing & $563^{\mathrm{B}}$ & $605^{\mathrm{A}}$ & $532^{c}$ & $540^{\mathrm{bc}}$ & $610^{\mathrm{ab}}$ & $655^{\mathrm{a}}$ & 0.040 & 0.002 & 62.1 \\
\hline Ewe rumination & 415 & 456 & 426 & 394 & 446 & 475 & 0.070 & 0.094 & 45.7 \\
\hline Ewe other activities & $462^{\mathrm{A}}$ & $379^{\mathrm{B}}$ & $482^{\mathrm{ab}}$ & $506^{\mathrm{a}}$ & $384^{\mathrm{bc}}$ & $310^{\mathrm{c}}$ & 0.030 & 0.005 & 100.8 \\
\hline Lambs total grazing & 491 & 477 & $346^{\mathrm{b}}$ & $434^{\mathrm{b}}$ & $568^{\mathrm{a}}$ & $589^{\mathrm{a}}$ & 0.50 & 0.001 & 114.4 \\
\hline Lambs rumination & 323 & 309 & $228^{\mathrm{c}}$ & $253^{\mathrm{bc}}$ & $351^{\mathrm{ab}}$ & $411^{\mathrm{a}}$ & 0.629 & 0.002 & 98.6 \\
\hline Lambs other activities & 626 & 654 & $866^{\mathrm{a}}$ & $753^{\mathrm{a}}$ & $521^{\mathrm{b}}$ & $440^{\mathrm{b}}$ & 0.570 & 0.001 & 205.2 \\
\hline Lambs “far-grazing” & 158 & 182 & $68^{c}$ & $157^{\mathrm{b}}$ & $219^{\mathrm{ab}}$ & $240^{\mathrm{a}}$ & 0.138 & 0.002 & 76.1 \\
\hline Lambs "near-grazing” & $333.4^{\mathrm{A}}$ & $296.5^{\mathrm{B}}$ & $276^{\mathrm{b}}$ & $275^{\mathrm{b}}$ & $350^{\mathrm{a}}$ & $358^{\mathrm{a}}$ & 0.021 & 0.002 & 49.4 \\
\hline
\end{tabular}

Values followed by different uppercase letters in the same line differ by Tukey test $(\mathrm{P}<0.05)$; Values followed by different lowercase letters in the same line differ by Tukey test $(\mathrm{P}<0.05)$.

Birth type had no significant effect on grazing time by lambs, but grazing time was significantly greater in periods 3 and 4, compared with periods 1 and 2. Similarly, the time spent ruminating by lambs was not significantly affected by birth type, but was significantly greater in period 3 and 4 , compared with period 1 . With the increase in the two main activities, the time expended in other activities reduces proportionally. About the lambs, the time spent by lambs grazing further than $12 \mathrm{~m}$ from the dam (far grazing, Table 4) was not affected by birth type, but increased significantly over the four periods. However, the time spent grazing nearer the dam was significantly greater in single lambs that in twins, and increased significantly in periods 3 and 4 . There was no significant birth type $\times$ period interactive effect on lambs grazing behaviour.

Using individual data from the lambs in each treatment and over the four periods, regression analyses was possible to determine the point at which the line representing far-grazing time (broken line) showed no further increase in response to lamb LW. This was calculated using non-parametric analysis and the change in direction of the straight line indicating the stabilization of the far grazing time for singles (Figure 1(a)) and twins (Figure 1(b)) lambs.

The broken line indicated when the lambs decreased their dependency on their dam, or in other words, when the lambs acquire experience to graze away from the proximity of its dam, inferred by the stabilization of far grazing time at a distance exceeding 12 meters. The weights beyond which far grazing time by singles and twin lambs ceased to increase (break in the line) did not differ significantly (20.6 and $20.1 \mathrm{~kg}$, respectively), occurring at mean LW of $20.3 \mathrm{~kg}$. By regression analysis, the age of the single and twin lambs at 20.6 and $20.1 \mathrm{~kg}$ LW, respectively, were calculated at to be 95.3 for singles and 115 days for twins.

\section{Discussion}

To obtain an unbiased measure of the birth type responses it was necessary to provide the same pasture conditions across treatments, principally the leaf mass and herbage allowance. By employing continuous variable stocking management to maintain an equal herbage allowance for each of the replicate groups, not differences in herbage composition or sward characteristics arose between the paddocks stocked by single- and twin-rearing ewes. In addition, [24] showed that, in Southern Brazil with annual ryegrass, better performance is achieved by keeping animals with a herbage allowance three times larger than potential consumption (12 kg DM/100kg LW). 


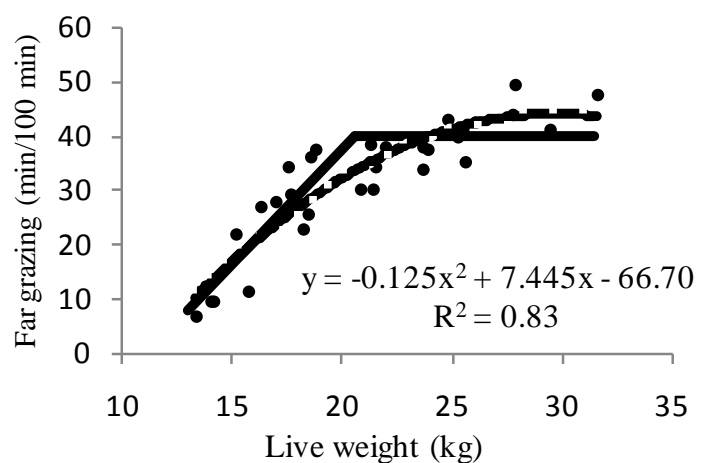

(a)

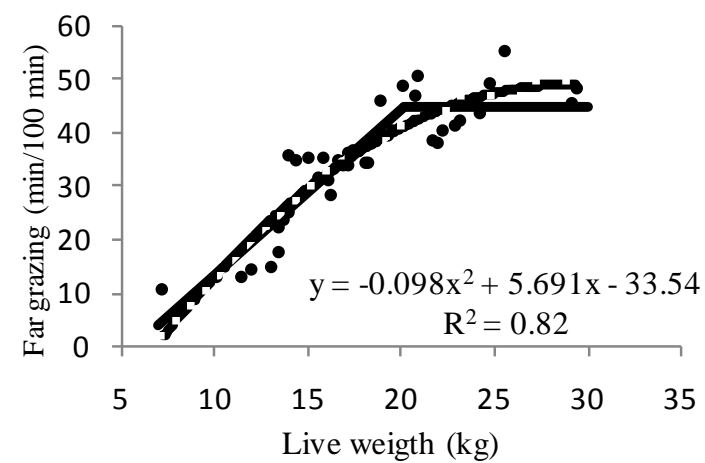

(b)

Figure 1. Changes in distance between ewes and their lambs ((a) Singles; (b) Twins) as a function of lambs live weight and far grazing time.

The decrease in white clover participation during the trial period was probably caused by two main factors. Firstly, sheep have a partial preference for about 70 per cent clover in their diet [25] and, by virtue of the narrow dental arcade and split upper lip, sheep are capable of grazing clover from within a mixed ryegrass/white clover sward. Secondly, due to the generous herbage allowance provided to the sheep, the height of the grass component of the sward may have impaired the ability of grazed clover plants to compete for light. The differences found over periods, such as increase in pseodostem can be linked with possible physiological explanations. One of them is an increase on tiller numbers with the constant removing of the leaves by grazing. On the other hand, is possible that the infrequent grazed area has contributed to increase the length of the pseudostem. While the proportionally rapid increase in dead herbage mass is an inevitable consequence of a high herbage allowance chose on this experiment.

However, results from several classic experiments conducted using sheep and cattle in various physiological states, all show a common asymptotic relationship between herbage allowance and herbage intake [26]-[28]. Reference [24] working with Italian ryegrass, found the break point for daily live weight gain with herbage allowance around 3.10 times the potential intake for sheep, were after that no performance improvement was observed. Data from these authors suggest that when is offered to the animals a herbage allowance 3 or 4 times their daily intake, around $66 \%$ or $75 \%$ of that material is remaining uneaten, contributing to the early plant maturity. Furthermore, the small increase in leaf mass (7.8\% over the four periods) contributed to the decline of leaf:pseudostem ratio between periods 1 and 4.

The ryegrass leaf/clover allowance, unlike the total herbage allowance, significantly declined over periods and can be explained by the decrease in clover participation in sward. Because, while the herbage allowance uses the total herbage mass for the herbage offer calculations, the ryegrass leaf/clover allowance uses only the ryegrass leaf mass and clover mass to perform the result.

Birth type did not affect the chemical composition of the samples plucked by hand to represent the herbage eaten. However, the quality of the herbage showed a reduction as the experiment progressed. The in-vitro OM digestibility showed little change over the first three periods, but declined in period 4, probably as a result of inclusion of some more mature lamina material in the samples, as supported by the significant increase in NDF content. The significant decline in crude protein over the periods is probably a reflection of a natural decline as ryegrass plants approach flowering, when the $\mathrm{N}$ content are more diluted in the plat tissues [29], exacerbated by the almost complete loss clover mass and reduced $\mathrm{N}$-fixation by the legume component of the sward.

Despite the numerical differences in total stocking rate (SR, $\mathrm{kg} / \mathrm{ha}$ ), this variable did not present difference between birth types and periods. The numerical difference is a result from the stocking adjustment to maintain the experimental protocol. The ewe stocking rate (SR ewes, $\mathrm{kg} / \mathrm{ha}$ ) did not present significant differences between birth types and periods, but ewes with twin lambs represent 8\% less live weight (50 kg LW) in the area. Although there was no significance in SR and SR ewes, the lamb stocking rate (SR lambs, kg/ha) was significant between birth types and periods. Over the four periods, the SR lambs increased mostly because the lambs grew.

At the start of the experiment, the SR lambs showed no significant differences between birth types, despite the 8\% of difference between them for live weight. However, due to the superior combined LW of twin pairs compared 
with single lambs, the difference within periods in the SR lambs increase and become significant for periods 2, 3 and 4. Considering the mean LW load of lambs occupation in the total SR, the twins represent $28 \%$ more LW ( $\mathrm{kg} / \mathrm{ha}$ ) than the single lambs. According to [30], the lamb category (single or twins) has the better animal performance (e.g. daily LW gains) and feed conversion when compared with other sheep categories. Using this statement, it becomes clear that ewes rearing twin lambs are more advantageous, mostly because there is more LW from lambs in the same area when compared with ewes rearing single lambs.

Twin-rearing ewes finished the trial with a lower body condition score than single-rearing ewes, due to greater mobilization of body reserves to meet the increased level of milk production. Previous studies [31] have shown twin rearing ewes to have limited ability to increase intake of herbage sufficiently to compensate for the increased demands of lactation, which are therefore met by mobilization of body tissues, mainly fat reserves. At the beginning of the trial, twin- and single-rearing ewes had mean live weights of $48.04( \pm 4.65)$ and 47.09 $( \pm 4.14) \mathrm{kg}$ respectively, and at the end mean live weights of $52.01( \pm 3.88)$ and $53.46( \pm 3.24) \mathrm{kg}$, respectively. Ewes showed similar individual performance throughout the experimental period, regardless of birth type. This may have occurred due to a large variability between the daily LW gains from individual ewes in different periods.

It is commonly found in the literature that single birth lambs have higher daily LW gains than twin lambs [6] [7]. This response was not observed in this experiment as single and twin lambs did not show significantly differences in the mean daily LW gains between birth types. However, the lambs had significant differences in their mean daily LW gains in the different periods. At the end of the period 1, a large number of animals were affected by foot-rot, which had a negative reflection on the mean LW gains in the period 2.

The daily LW gains, when expressed on a per unit area basis showed that, ewes with twin lambs achieved a $42 \%$ greater mean LW output than those with singles during the trial period, attributable solely to the greater production of the lambs, because no significance difference in the LW output from ewes are achieved. Comparing the overall (sum of four periods) LW output, the twin lambs produced $116 \mathrm{~kg}$ more output per area then the single lambs, representing $43 \%$ more LW output on a per unit area basis.

Usually, the main variables used in local protocols to measure the productivity of birth types are only the lambs' individual performances (daily LW gain) and the time from birth to slaughter [5]-[7], which may provide confusion in data interpretation if the purpose is to compare productivity of different birth types. Because of that, the comparison of results can be difficult to make with the present trial. An important consideration in this type of protocol is the feeding control, which should be similar for the different birth types, so that they can be compared. Furthermore, to be able to compare the productivity of birth types, more important than individual performances are to estimate the system area productivity, as LW outputs per area unit or meat production per area unit. In situations using time to slaughter, the time taken for lambs to reach the ideal weight is important, but in these situations, the amount of meat produced are more important, even if little more time is required to reach the ideal weight.

Measurements of grazing behavior showed that ewes with twin lambs grazed a mean of 42 minutes more $(+7 \%)$ each day, than ewes with singles lambs. Previous research has shown variable effects of birth type on herbage intake in early lactation. Referred [9] reported a slightly greater intake (6\%) by twin-rearing ewes, compared with single-rearing ewes, with maximum intakes occurring in weeks 5 and 4 of lactation, respectively. Referred [31] reported no significant overall effect of birth type on herbage intakes, with maximum intakes occurring in weeks 3 and 4 of lactation, although intakes may have been reduced prematurely due to adverse weather conditions. Such slight differences in patterns of intake may well reflect the grazing and ewe conditions in their respective experiments. In the present trial, the first two assessments of behavior took place in weeks 7 and 12 of lactation, when the ewes with twins grazed for 42 minutes longer per day than those with singles. Assessments made in weeks 16 and 20 of lactation, continued to show differences of 70 and 54 minutes longer grazing time for twin ewes, respectively. The relatively change on grazing behavior times in early lactation thus appear to reflect attempts by ewes to meet the greater nutritional requirements for milk production to support twin lambs, compared with a single lamb.

Although the times spent ruminating by ewes with single and twins were not statistically different during the trial, overall, ewes with twins ruminated for 41 minutes longer, reflecting the differences in grazing time. The difference in time spent on other activities differed significantly between birth types, reflecting the greater (8\%) collective time requirement for eating and ruminating by ewes with twins. Significant differences in grazing time existed between periods, with an increase of over 80 minutes from period 1 to 4. Evidence from [9] [31] is 
that herbage intake by lactating ewes peaks during week 2 to 4 of lactation, and declines thereafter. The increase in grazing time over periods 1 to 4 in the present experiment were undoubtedly due to an increase in the searching element of grazing activity as the leaf:pseudostem ratio declined and senescent material accumulated in the sward. The relatively small decrease in OM digestibility of herbage representative eaten demonstrates how well they could have maintained the quality of their diet from a deteriorating sward.

The intake of grazed herbage by lambs increases as they grow, although the rate of increase will be influenced by milk intake [32], herbage allowance and competition with their dams [33]. However, the increase in grazing time over the course of the present experiment will have been in response to, not only the increased herbage intake requirement due to growth and declining milk intake, but a reduction in short-term intake rate as a result of the increased searching and handling necessitated by the deterioration of the sward. The increase in ruminating time in this experiment would have been due to the reduction in OM digestibility and increase in fiber content of the herbage eaten over time.

Young lambs are highly dependent on their dams and follow them closely in the first weeks of life due to their reliance upon her for milk [22] and, when they start to graze, remain in close contact to gain experience through observation [34]. At the start in graze activity and with rumen development, lambs will tend to distance itself from the ewe, around 8 meters [35], but with frequent encounters between them for suckling [22]. With increased maturity, these encounters diminish, mostly because there is less milk available to them, causing an optimization and increase in time spent searching and consuming herbage [36], but also because of the increasing experience and confidence of the lambs.

Sheep, as herd grazers, are gregarious animals so the distance will never be very great [37]. The detachment of the lamb is strongly influenced by paddock size and results from of acquired security over time (predation pressure; [23]), including previous management experiences to which they may have been subjected. In the present experiment, there was a significant increase in both near and far grazing time over periods 1 to 4 . Overall, twins spent 37 minutes less time grazing near their dams than single lambs. This could be attributed to the twin lambs needing to venture further from their dam to graze, in response to the lower availability of milk, and indeed there was a concomitant (though non-significant) increase in far grazing time of 26 minutes by the twin lambs. However, any propensity for twin lambs to consume more herbage in response to lower milk intake, will have been partly offset by their lower ( $>3 \mathrm{~kg}$ ) LW thought periods 1 to 4 .

In addition to understanding the relationships the pasture and grazing animals, this study also involved a study of how lamb grazing behavior, such as increased exploration efficiency, could be used to identify suitable management criteria for improving animal production and maximizing animal welfare. According to [38], animals develop behaviors specific to their pastoral environment, which if recognized can provide an important tool for grazing management.

Such a possible diagnostic behavior was investigated by analysis performed with the aid of broken line method. This was used to try to demonstrate that the moment that the lamb gets the "maximum confidence" and "all experience they need" to maintain their self in a pasture environment, without or independent of their dam, may occurs at about $20.3 \mathrm{~kg} \mathrm{LW}$ in both birth types, independent of age. This LW represents $33 \%$ of the mature weight in these crossbred lambs and occurred at 95.3 and 115.9 days of age for single and twin lambs, respectively. The moment of the maximum experience occurs by an interaction between age and LW, but, according to [39], the weight is better correlated to indicate an animal development. In the same way that the sexual maturity of the ewe lambs is frequently judged by their LW, because it shows a higher correlation than age with body development [40] so, other aspects of developmental maturity may well be correlated with live weight. According to the same author, independent of the animals age, the sexual maturity only will be expressed when the target weight will be reached.

Due to these findings, it may be necessary to rethink the current local criteria used to determine when lambs should be weaned, especially if they are replacement ewe lambs and will not have a special diet, such as supplements, after weaning and only will be kept at pasture. It is common practice for lambs to be weaned at a fixed date, which can prejudice the post-weaning performance of lighter lambs (frequently the twins) compromising their productivity and welfare. In post-weaning experimental situations, if the lambs were weaned using a fixed date, probably they will be different LW at weaning time, what could be a "vies", mostly because the lambs are in different experience stages. According to [36], heavier and older lambs suffer less stress at weaning, suggesting that this management needs to be conducted as late as possible, because lambs have a more experience if feeding themselves, which improves its performance after weaning. Nevertheless, we cannot affirm that our 
results about the "experience of the lambs" are accurately applicable, mostly due an increase in the grazing time close to their dam (near grazing time) after the stabilization of the line in the Figures 1(a) and (b). Although, more research is needed to substantiate our obtained results.

\section{Conclusion}

The results of this study have shown that, in the same sward conditions with an optimum forage offer, twin-lamb systems are more productive than single-lamb systems on an equal area of land.

\section{References}

[1] Anuário da Pecuária Brasileira-ANUALPEC. (2011) São Paulo: Instituto FNP.

[2] Allen, V.G., Batello, C., Berretta, E.J., Hodgson, J., Kothmann, M. and Li, X. (2011) An International Terminology for Grazing Lands and Grazing Animals. Grass Forage Science, 66, 2-28. http://dx.doi.org/10.1111/j.1365-2494.2010.00780.x

[3] Bandinelli, D.G., Gatiboni, L.C., Trindade, J.P.P., Quadros, F.L.F., Kaminski, J., Flores, J.P.C., et al. (2005) Composição florística da pastagem natural afetada por fontes de fósforo, calagem e introdução de espécies forrageiras de estação fria. Ciência Rural, 35, 84-91. http://dx.doi.org/10.1590/S0103-84782005000100013

[4] Moojen, E.L. and Maraschin, G.E. (2002) Potencial produtivo de uma pastagem nativa do Rio Grande do Sul submetida a níveis de oferta de forragem. Ciência Rural, 32, 127-132. http://dx.doi.org/10.1590/S0103-84782002000100022

[5] Carneiro, R.M., Pires, C.C., Muller, L., Kippert, C.J., Costa M.L., Colome, L.M., et al. (2004) Ganho de peso e eficiência alimentar de cordeiros de parto simples e duplo desmamados aos 63 dias de idade e não desmamados. Revista Brasileira de Agrociência, 10, 227-230. http://www2.ufpel.edu.br/faem/agrociencia/v10n2/artigo14.pdf

[6] Pires, C.C., Carneiro, R.M., Muller, L., Souza, J.H.S., Cardoso, A.R., Neto, D.P., et al. (2006) Avaliação de carcaças e componentes do peso vivo de cordeiros de parto simples desmamados, parto simples não desmamados e parto duplo desmamados. Revista Brasileira de Agrociência, 12, 93-97. http://www2.ufpel.edu.br/faem/agrociencia/v12n1/artigo17.pdf

[7] Pires, C.C., Muller, L., Griebler, L., Hastenpflug, M., Wommer, T. and Carvalho, S. (2012) Produção, qualidade do leite e desempenho de cordeiros de partos simples e duplo em pastagem de azevém. Zootecnia Tropical, 30. http://www.scielo.org.ve/scielo.php?pid=S0798-72692012000200001\&script=sci arttext

[8] Rattray, P.V., Thompson, K.F. and Hawker, H. (2007) Pastures for Sheep Production. In: Nicol, A.M., Ed., Livestock Feeding on Pasture, New Zealand Society of Animal Production, Hamilton, 89-104.

[9] Maxwell, T.J., Doney, J.M., Milne, J.A., Peart, J.N., Russel, A.J.F., Sibbald, A.R., et al. (1979) The Effect of Rearing Type and Prepartum Nutrition on the Intake and Performance of Lactating Greyface Ewes at Pasture. Journal of Agricultural Science, 92, 165-174. http://dx.doi.org/10.1017/S0021859600060615

[10] Moreno, J.A. (1961) Clima do Rio Grande do Sul. Porto Alegre: Secretaria da Agricultura, 41p.

[11] Wilm, H.G., Costelo, O.F. and Klippe, G.E. (1944) Estimating Forage Yield by the Double Sampling Method. Journal American Society of Agronomy, 36, 194-203. http://dx.doi.org/10.2134/agronj1944.00021962003600030003x

[12] Klingman, D.L., Miles, S.R. and Mott, G.O. (1943) The Cage Method for Determining Consumption and Yield of Pasture Herbage. Journal of American Society Agronomic, Geneva, 35, 739-746. http://dx.doi.org/10.2134/agronj1943.00021962003500090001x

[13] Euclides, V.P.B., Macedo, M.C.M. and Oliveira, M.P. (1992) Avaliação de diferentes métodos de amostragens sob pastejo. Revista Brasileira de Zootecnia, Viçosa, 21, 691-702. http://dx.doi.org/10.1590/S1516-35982005000100004

[14] AOAC (1960) Official Methods of Analysis. 10th Edition, Association of Official Analytical Chemists, Washington DC.

[15] AOAC (1975) Official Methods of Analysis. 12th Edition, Association of Official Analytical Chemists, Washington DC.

[16] Tilley, J.M.A. and Terry, R.A. (1963) A Two-Stage Technique for the in Vitro Digestion of Forage Crop. Grass and Forage Science, 18, 104-111. http://dx.doi.org/10.1111/j.1365-2494.1963.tb00335.x

[17] Robertson, J.B. and Van Soest, P.J. (1981) The Detergent System of Analysis. In: James, W.P.T. and Theander, O., Eds., The Analysis of Dietary Fiber in Food, Marcel Dekker, New York, Chapter 9, 123-158.

[18] Russel, J. F., Doney M. and Gunn, R. (1969) Subjective Assessment of Body Fat in Live Sheep. Journal Agricultural Science, 72, 451-454. http://dx.doi.org/10.1017/S0021859600024874

[19] Gary, L.A., Sherritt, G.W. and Hale, E.B. (1970) Behavior of Charolais Cattle on Pasture. Journal of Animal Science, 
30, 303-306.

[20] Hancock, J. (1953) Grazing Behaviour of Cattle. Animal Breeding Abstract, Farnham Royal, 21, 1-13.

[21] Forbes, T.D.A. (1988) Researching the Plant-Animal Interface: The Investigation of Ingestive Behavior in Grazing Animals. Journal of Animal Science, 66, 2369-2379.

[22] Fisher, A. and Matthews, L. (2001) The Social Behaviour of Sheep. In: Keeling, L., Ed., Social Behaviour in Farm Animals, Swedish University of Agricultural Sciences, Skara, 211-245. http://dx.doi.org/10.1079/9780851993973.0211

[23] Lindenberg, A.C. (2001) Group Life. In: Keeling, L.J. and Gonyou, H.W. (Eds.), Social Behaviour in Farm Animals, CAB International, Wallingford, 37-59 http://dx.doi.org/10.1079/9780851993973.0037

[24] Azevedo, E.B. (2011) Consumo e utilização de nutrientes por ovinos em pastagem de azevem annual. Doctoral Thesis, Universidade Federal do Rio Grande do Sul, Porto Alegre, 345p.

[25] Rutter, S.M. (2006) Diet Preference for Grass and Legumes in Free-Ranging Domestic Sheep and Cattle: Current Theory and Future Application. Applied Animal Behaviour Science, 97, 17-35.

http://dx.doi.org/10.1016/j.applanim.2005.11.016

[26] Greenhalgh, J.F.D., Reid, G.W. and McDonald, I. (1966) The Indirect Estimation of the Digestibility of Pasture Herbage. IV. Regressions of Digestibility of Faecal Nitrogen Concentration: Effects of Different Fractions of the Herbage Upon within-and between Period Regressions. Journal of Agricultural Science, 66, 277-283. http://dx.doi.org/10.1017/S0021859600062699

[27] Jamieson, W.S. and Hodgson, J. (1979) The Effect of Variation in Sward Characteristics upon the Ingestive Behavior and Herbage Intake of Calves and Lambs under Continuous Stocking Management. Grass Forage Science, 34, 273281. http://dx.doi.org/10.1111/j.1365-2494.1979.tb01479.x

[28] Peyraud, J.L., Comeron, E.A. and Wade, M.H. (1996) The Effect of Daily Herbage Allowance, Herbage Mass and Animal Factors upon Herbage Intake by Grazing Dairy Cows. Annales Zootechnie, 45, 201-217. http://dx.doi.org/10.1051/animres:19960301

[29] Lemaire, G. and Chapman, D. (1996) Tissue Flows in Grazed Plant Communities. In: Hodgson, J. and Illius, A.W., Ed., The Ecology and Management of Grazing Systems, CAB, Wallingford, 3-36.

[30] Pires, C.C., Silva, L.F., Schlick, F.E., Guerra, D.P., Biscaino, G. and Carneiro, R.M. (2000) Cria e terminação de cordeiros confinados. Ciência Rural, 30, 875-880. http://dx.doi.org/10.1590/S0103-84782000000500023

[31] Gibb, M.J. and Treacher, T.T. (1982) The Effect of Body Condition and Nutrition during Late Pregnancy on the Performance of Grazing Ewes during Lactation. Animal Production, 34, 123-129. http://dx.doi.org/10.1017/S0003356100000593

[32] Penning, P.D. and Gibb, M.J. (1979) The Effect of Milk Intake on the Intake of Cut and Grazed Herbage by Lambs. Animal Production, 29, 53-67. http://dx.doi.org/10.1017/S0003356100012150

[33] Gibb, M.J., Treacher, T.T. and Shanmugalingam, V.S. (1981) Herbage Intake and Performance of Grazing Ewes and of Their Lambs When Weaned at 6810 or 14 Weeks of Age. Animal Production, 33, 223-232. http://dx.doi.org/10.1017/S0003356100031585

[34] Lynch, J.J., Keogh, R.G., Elwin, R.L., Green, G.C. and Motthershead, B.C. (1983) Effects of Early Experience on the Post-Weaning Acceptance of Whole Grain Wheat by Fine Wool Merino Lambs. Animal Production, 36, 175-183. http://dx.doi.org/10.1017/S1357729800001223

[35] Shackleton, D.M. and Haywood, J. (1985) Early Mother-Young Interactions in California Bighorn Sheep, Ovis Canadensis californiana. Canadian Journal of Zoology, 63, 868-875. http://dx.doi.org/10.1139/z85-129

[36] Schichowski, C., Moors, E. and Gauly, M. (2008) Effects of Weaning Lambs in Two Stages or by Abrupt Separation on Their Behavior and Growth Rate. Journal of Animal Science, 86, 220-225. http://dx.doi.org/10.2527/jas.2007-0198

[37] Jensen, P. (2002) Behaviour Genetics, Evolution and Domestication. In: Jensen, P., Ed., The Ethology of Domestic Animals, CABI Publishing, Wallingford, 13-30. http://dx.doi.org/10.1079/9780851996028.0013

[38] Carvalho P.C.F., Trindade, J.K.; Mezalira, J.C., Poli, C.H.E.C., Nabinger, C., Genro, T.C.M. (2009) Do bocado ao pastoreio de precisão: Compreendendo a interface planta-animal para explorar a multi-funcionalidade das pastagens. Revista Brasileira de Zootecnia, 38, 109-122. http://www.scielo.br/pdf/rbz/v38nspe/v38nspea13.pdf

[39] Orgeur, P., Mavric, N., Yvore, P., Bernard, S., Nowak, R., Schaal, B., et al. (1997) Artificial Weaning in Sheep: Consequences on Behavioural, Hormonal and Immuno-Pathological Indicators of Welfare. Applied Animal Behaviour Science, 58, 87-103. http://dx.doi.org/10.1016/S0168-1591(97)00140-8

[40] Cupps, P.T. (1991) Reproduction in Domestic Animals. 4th Edition, Academic Press, San Diego, 670p. 